\title{
Effect of interfacial area on densification and microstructural evolution in silicon carbide-boron carbide particulate composites
}

\author{
Tom Williams $^{1} \cdot$ Julie Yeomans $^{1} \cdot$ Paul Smith $^{1} \cdot$ Andrew Heaton $^{2} \cdot$ \\ Chris Hampson ${ }^{3}$
}

Received: 2 June 2015/Accepted: 22 August 2015/Published online: 15 September 2015

(C) The Author(s) 2015. This article is published with open access at Springerlink.com

\begin{abstract}
A range of $\mathrm{SiC}-\mathrm{B}_{4} \mathrm{C}$ composites have been prepared by pressureless sintering, using different proportions of two sizes of $\mathrm{B}_{4} \mathrm{C} ; 7$ and $70 \mu \mathrm{m}$. The interfacial area between the $\mathrm{B}_{4} \mathrm{C}$ and $\mathrm{SiC}$ has been quantified and is shown to have a significant effect on both densification and the resultant microstructure of the composites. $\mathrm{SiC} / \mathrm{B}_{4} \mathrm{C}$ interfaces typically hinder densification. $\mathrm{SiC} / \mathrm{B}_{4} \mathrm{C}$ interfacial area is also shown to be related to grain growth and polytype distribution in the $\mathrm{SiC}$. With more $\mathrm{SiC} / \mathrm{B}_{4} \mathrm{C}$ interfacial area, grain growth in the $\mathrm{SiC}$ is restricted and less of the $\mathrm{SiC}$ transforms from the starting $6 \mathrm{H}$ polytype to the $4 \mathrm{H}$ one. It is therefore suggested that it may be possible to use $\mathrm{SiC} / \mathrm{B}_{4} \mathrm{C}$ interfacial area as a means by which to engineering the microstructure.
\end{abstract}

\section{Introduction}

$\mathrm{SiC}$ and $\mathrm{B}_{4} \mathrm{C}$ are of interest owing to their combination of high hardness, low density and high thermal tolerance, even when compared with other common engineering ceramics. However, $\mathrm{B}_{4} \mathrm{C}$ is known to be difficult, and thus costly, to form into a dense body, particularly by pressureless sintering. This is because of its highly covalent structure and corresponding low self-diffusivity [1]. Despite these drawbacks, because it has a lower density than $\mathrm{SiC}$ and can display higher hardness, significant

Tom Williams

tom.williams@morganplc.com

University of Surrey, Guildford, UK

Dstl, Salisbury, UK

3 Morgan Advanced Materials, Stourport on Severn, UK interest in its use remains. Given that $\mathrm{SiC}$ and $\mathrm{B}_{4} \mathrm{C}$ have some capacity to act as sintering aids for each other, composite materials have been suggested as a pragmatic approach to producing carbide ceramic materials. Further, in spite of the associated difficulties, pressureless sintering of these materials is preferred to hot pressing techniques, if the resulting composites are to be commercially viable. Reaction bonding has also been used to produce these composites [2], but results in reduced hardness and strength compared with sintered materials [3] and so is of less interest for high performance applications. Use of coarser $\mathrm{B}_{4} \mathrm{C}$ also has the potential to reduce the cost of the material. However, this may impair the ability of a composite to densify, given the low self-diffusivity of $\mathrm{B}_{4} \mathrm{C}$. This is significant since a primary consideration in components where hardness is important, such as those for wear applications, is that materials must reach a high percentage of their theoretical density (\%TD). When using fine $\mathrm{B}_{4} \mathrm{C}$, composites with compositions ranging from 10 to $90 \mathrm{wt} \% \mathrm{~B}_{4} \mathrm{C}$ have been pressureless sintered to $98 \% \mathrm{TD}$, with only $\mathrm{C}$ additions [4]; this suggests that almost full densification is possible under the correct conditions. However, it has also been reported that $\mathrm{B}_{4} \mathrm{C}$ will not demonstrate self-densification with a particle size (as indicated by a median diameter, $d_{50}$, value) above $\sim 8 \mu \mathrm{m}$ [5]. One potential solution to this is to surround a coarse $\mathrm{B}_{4} \mathrm{C}$ material with a $\mathrm{SiC}$ matrix, which can be readily prepared with $\mathrm{B}$ and $\mathrm{C}$ additives to achieve good densification more readily than $\mathrm{B}_{4} \mathrm{C}$.

As well as $\% \mathrm{TD}$, the grain structure is important in determining the mechanical performance of the ceramic material. $\mathrm{SiC}$ has long been known to display discontinuous grain growth, both under liquid phase sintering (LPS) [6], and also under solid state sintering conditions [7, 8]. Discontinuous grain growth is more common under 
pressureless sintering conditions than under pressure-assisted densification, since higher temperatures are typically required to produce adequate density in the sintered body. The use of a second inert phase, such as graphite, has been demonstrated to limit this [9]. Similar effects have been achieved in $\mathrm{Al}_{2} \mathrm{O}_{3}$, using $\mathrm{B}_{4} \mathrm{C}$ as an inert phase $[10,11]$. However, the degree of control of grain growth that may be achieved using a second phase is not well understood. A distinct trend has been observed for $\mathrm{B}$, (added as $\left.\mathrm{B}_{4} \mathrm{C}\right)$ in $\beta$ $\mathrm{SiC}$ [12]. It was observed that the addition of a small amount of B increased grain growth; this is in agreement with previous work suggesting that B typically increases diffusivity and mass transport in $\mathrm{SiC}$ [13]. However, further addition of $\mathrm{B}_{4} \mathrm{C}$ inhibited grain growth. Since $\mathrm{B}$ has a low solid solubility in $\mathrm{SiC}$ [14], the remaining $\mathrm{B}_{4} \mathrm{C}$ was likely to be inert. This suggests that the interfaces present between $\mathrm{SiC}$ and $\mathrm{B}_{4} \mathrm{C}$ were inhibiting grain growth, as was observed with graphite addition [9] and when $5 \mathrm{wt} \% \mathrm{~B}_{4} \mathrm{C}$ prevented discontinuous grain growth in a pressureless sintered $\mathrm{SiC}$ [15].

Sintering of $\mathrm{SiC}$ is also linked to changes in the polytype composition of the material, which may be important since it has been suggested that polytype transformations could act as a micro-plasticity mechanism under certain conditions [16]. Polytype transformation has been observed by Raman spectroscopy in $\mathrm{SiC}$ subject to machining [17] but is more commonly associated with certain grain growth mechanisms, including $\beta$ to $\alpha$ transformation by dissolution-precipitation during LPS [18]. In $\alpha$-SiC, it has also been observed that LPS $6 \mathrm{H} \mathrm{SiC}$ tends to transform to $4 \mathrm{H}$ when abnormal grain growth occurs when an aluminiumboron-carbon (ABC) phase is used [19-21]. Further, in a related study, increased transformation from $6 \mathrm{H}$ to $4 \mathrm{H}$ was observed with increased sintering temperature for LPS $\alpha$ $\mathrm{SiC}$ [22]. However, LPS seems to produce a smaller effect on polytype transformation in $\alpha$-SiC than in $\beta$-SiC [23]. This may result from the greater thermal stability of $6 \mathrm{H}$ $\mathrm{SiC}$ compared with $3 \mathrm{C}$. For both $3 \mathrm{C}$ and $6 \mathrm{H} \mathrm{SiC}$, however, the transformation to $4 \mathrm{H}$ is typically associated with the formation of a liquid phase and also therefore with grain growth.

Given that it appears that a second phase in these materials can influence the microstructural evolution in $\mathrm{SiC}$, it is necessary to consider means of quantifying the degree of interaction between two phases. This can be accomplished using image segmentation methods, such as phase separation [24]. However, in the present work, the total $\mathrm{SiC} / \mathrm{B}_{4} \mathrm{C}$ interfacial area/unit volume in different material has been quantified directly.

In the present work, particulate $\mathrm{SiC}-\mathrm{B}_{4} \mathrm{C}$ composites have been produced by adding two relatively coarse grades of $\mathrm{B}_{4} \mathrm{C}$ to a $\mathrm{SiC}$ matrix. The effects of the $\mathrm{SiC} /$ $\mathrm{B}_{4} \mathrm{C}$ interfacial area in these composites are discussed.
It is suggested that the interfacial area affects densification, together with material diffusivity and powder size effects. Further, the amount of $\mathrm{SiC} / \mathrm{B}_{4} \mathrm{C}$ interfacial area has a significant effect on the microstructural evolution, changing the grain size and type within the $\mathrm{SiC}$ matrix.

\section{Experimental procedure}

All samples were prepared with an $\alpha$-SiC starting powder, (SIKA Sintex $15 \mathrm{C}$ ) with $d_{50}$ measured as $0.8 \mu \mathrm{m}$ on a Malvern Mastersizer 3000, surface area $15 \pm 1 \mathrm{~m}^{2} \mathrm{~g}^{-1}$ and $0.83 \mathrm{wt} \%$ total $\mathrm{O}$. Two sizes of $\mathrm{B}_{4} \mathrm{C}$ were used with $d_{50}$ values of approximately 7- and 70- $\mu \mathrm{m}$ (Sigma Aldrich research purity $\mathrm{B}_{4} \mathrm{C}$ ). According to LECO analysis provided by AMG analytical services, Rotherham, UK, the $7-\mu \mathrm{m}$ Sigma grade has $0.160 \mathrm{wt} \% \mathrm{O}$ and $70-\mu \mathrm{m}$ Sigma grade has $0.041 \mathrm{wt} \% \mathrm{O}$.

Powder blends were prepared by dispersion of both $\mathrm{SiC}$ and the $\mathrm{B}_{4} \mathrm{C}$ powders in a slip. To facilitate densification in the $\mathrm{SiC}, 1 \mathrm{wt} \%$ of $1-\mu \mathrm{m} \mathrm{B}{ }_{4} \mathrm{C}, \mathrm{H}$. C. Starck HS grade, and an organic $\mathrm{C}$ source (yielding approximately $4 \mathrm{wt} \% \mathrm{C}$ ) were added to all powder blends. A fugitive binder system was also added to all blends. Materials with $\mathrm{B}_{4} \mathrm{C}$ additions of 10, 20 and $30 \mathrm{wt} \%$ were prepared with both the 7- and $70-\mu \mathrm{m}$ grades. All powder blends contained $\mathrm{SiC}$ as the remaining $\mathrm{wt} \%$, forming the matrix phase. A standard $\mathrm{SiC}$, containing $1 \mathrm{wt} \%$ of the $1-\mu \mathrm{m} \mathrm{B}_{4} \mathrm{C}$ and the $\mathrm{C}$ source, but no coarse $\mathrm{B}_{4} \mathrm{C}$ was also prepared as a reference material. The resulting slips were freeze dried and sieved through a $355-\mu \mathrm{m}$ mesh. Discs of $20 \mathrm{~mm}$ diameter, approximately $5 \mathrm{~mm}$ thick were prepared, by uniaxial pressing at $345 \pm 2 \mathrm{MPa}$. Sintering of all parts was carried out in graphite trays in a graphite resistance furnace under Ar. A top temperature of $2125{ }^{\circ} \mathrm{C}$ with a hold of $1 \mathrm{~h}$ was used for all samples.

Sample mass was measured using a Mettler-Toledo balance to $\pm 0.001 \mathrm{~g}$ and density was calculated using the Archimedes method in reverse osmosis (RO) water. The $\%$ TD was calculated from the density using the rule of mixtures and assuming densities of 3.20 and $2.52 \mathrm{~g} \mathrm{~cm}^{-3}$ for $\mathrm{SiC}$ and $\mathrm{B}_{4} \mathrm{C}$, respectively. Five sample discs of each material were measured in this way. Samples were polished metallographically; the final step used a $1 \mu \mathrm{m}$ diamond slurry. Scanning electron microscopy (SEM) characterisation was carried out using a JEOL 6000 desktop SEM with a back scattered electron (BS) detector. Accelerating voltage was $10 \mathrm{kV}$, working distance $19 \mathrm{~mm}$. X-ray diffraction (XRD) was carried out on a Hitachi Gen 3 model with a monochromater using $\mathrm{Cu} K \alpha$ radiation. Generator settings were $35 \mathrm{kV}$ and $40 \mathrm{~mA}$. Scan range was $5^{\circ}-120^{\circ} 2 \theta$, with a $0.017^{\circ}$ step and a $4 \mathrm{~s}$ dwell. Samples 
were then etched by heating to $850^{\circ} \mathrm{C}$ in air for $1 \mathrm{~h}$ and boiling in a Murakami's reagent. Reflected light microscopy was carried out on a Buhler instrument. Image analysis was carried out using ImageJ software and Rietveld refinement were carried out using General Structure Analysis Software (GSAS). Data for this refinement were obtained from the international crystal structures database $[25,26,27]$. For grain size analysis, direct measurement was used, by drawing lines along the long axes of grains on representative micrographs of each material and recording the lengths of these. At least 150 grains/material were measured.

To assess the amount of $\mathrm{SiC} / \mathrm{B}_{4} \mathrm{C}$ interfacial area in a given composite volume, an 'edge area' method was adopted, using BS SEM images of polished samples. All required image analysis was carried out using ImageJ software. The 'edge area' method used thresholding to select $\mathrm{B}_{4} \mathrm{C}$ features in a given $\mathrm{BS}$ SEM image to produce a simple binary image and then the 'find edges' tool, a 3 by 3 sobel edge filter, to produce an image consisting solely of the lines representing the $\mathrm{SiC} / \mathrm{B}_{4} \mathrm{C}$ interfaces. $\mathrm{B}_{4} \mathrm{C}$ is appreciably darker than $\mathrm{SiC}$ in these images and pores are darker again than the $\mathrm{B}_{4} \mathrm{C}$, producing three distinct shades. Thus, it is possible to select only $\mathrm{B}_{4} \mathrm{C}$. The stages to produce this image are shown in Fig. 1. From examination of different material orientations, including through thickness, it appears that the $\mathrm{B}_{4} \mathrm{C}$ distribution is generally isotropic. Hence, the perimeter length of the $\mathrm{B}_{4} \mathrm{C}$ feature edges/unit area is related to the actual interfacial area/unit volume. The edge lines have finite thickness, and so the total edge area on the image was recorded as a fraction of the total image area. This value was converted to the interface perimeter/unit area and hence interface area/unit volume in 3D, by dividing it by the mean interface line thickness. Image smoothing was used to reduce the error from edge detection around pores. This was necessary because pores showed an appreciable contrast difference with the surrounding material, and it was otherwise impossible to use the 'find edges' tool without detecting pore edges. Five representative micrographs for each sample were analysed in this way.

\section{Results and discussion}

\section{Interfacial area}

Example micrographs of the type used to measure the interfacial area for the composition ranges tested are shown in Fig. 2. The interfacial area/unit volume measured in the composites is shown in Fig. 3 as a function of $\mathrm{B}_{4} \mathrm{C}$ content. The graph shows that the interfacial area/unit volume between the phases is increased both by increasing the amount of $\mathrm{B}_{4} \mathrm{C}$ and by reducing the $\mathrm{B}_{4} \mathrm{C}$ size, thereby (a)

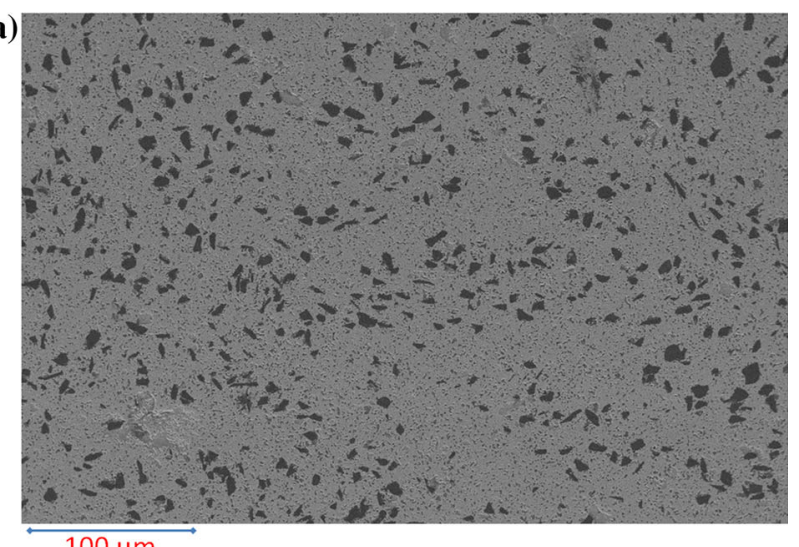

$100 \mu \mathrm{m}$

(b)

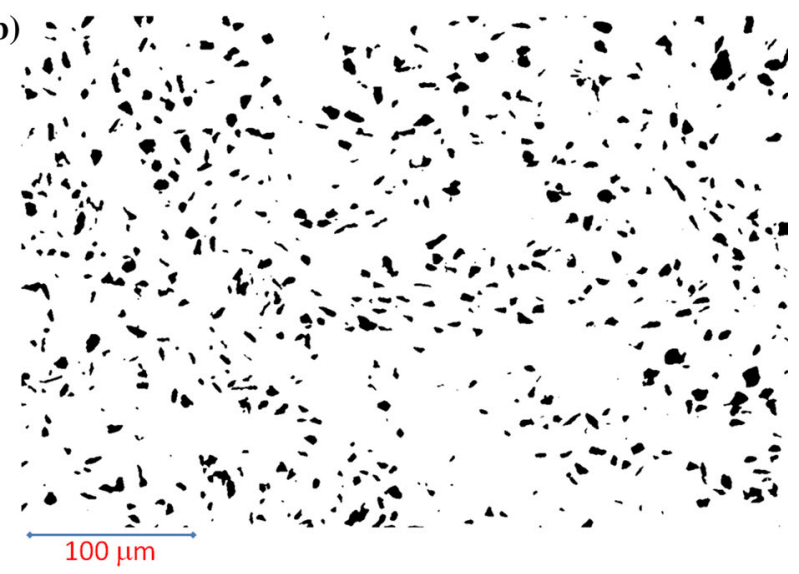

(c)

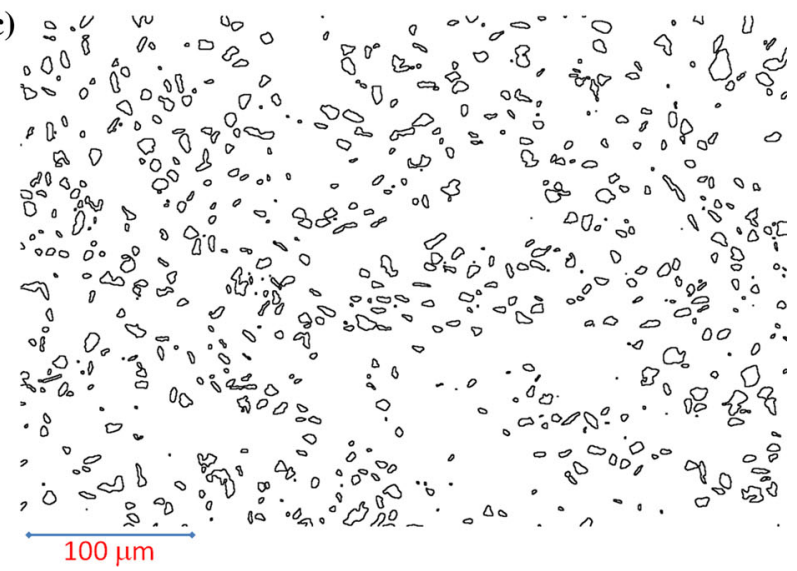

Fig. 1 Images showing determination of $\mathrm{SiC} / \mathrm{B}_{4} \mathrm{C}$ interfacial area from a BS SEM micrograph-a original micrograph (in which $\mathrm{B}_{4} \mathrm{C}$ is the darker phase), $\mathbf{b} \mathrm{B}_{4} \mathrm{C}$ features selected by thresholding shown in black, $\mathbf{c}$ perimeters of $\mathrm{B}_{4} \mathrm{C}$ features with lines of finite thickness

increasing the surface area to volume ratio. Critically, the $\mathrm{SiC} / \mathrm{B}_{4} \mathrm{C}$ interfacial area is comparable between materials with $10 \mathrm{wt} \% 7-\mu \mathrm{m} \mathrm{B} \mathrm{B}_{4} \mathrm{C}$ and $20 \mathrm{wt} \% 70-\mu \mathrm{m} \mathrm{B} \mathrm{B}_{4} \mathrm{C}$ and also to a lesser extent between materials with $20 \mathrm{wt} \% 7-\mu \mathrm{m}$ $\mathrm{B}_{4} \mathrm{C}$ and $30 \mathrm{wt} \% 70-\mu \mathrm{m} \quad \mathrm{B}_{4} \mathrm{C}$. Hence, if the $\mathrm{SiC} / \mathrm{B}_{4} \mathrm{C}$ interfacial area is important to a given property, these two pairs of materials should demonstrate similar values. 

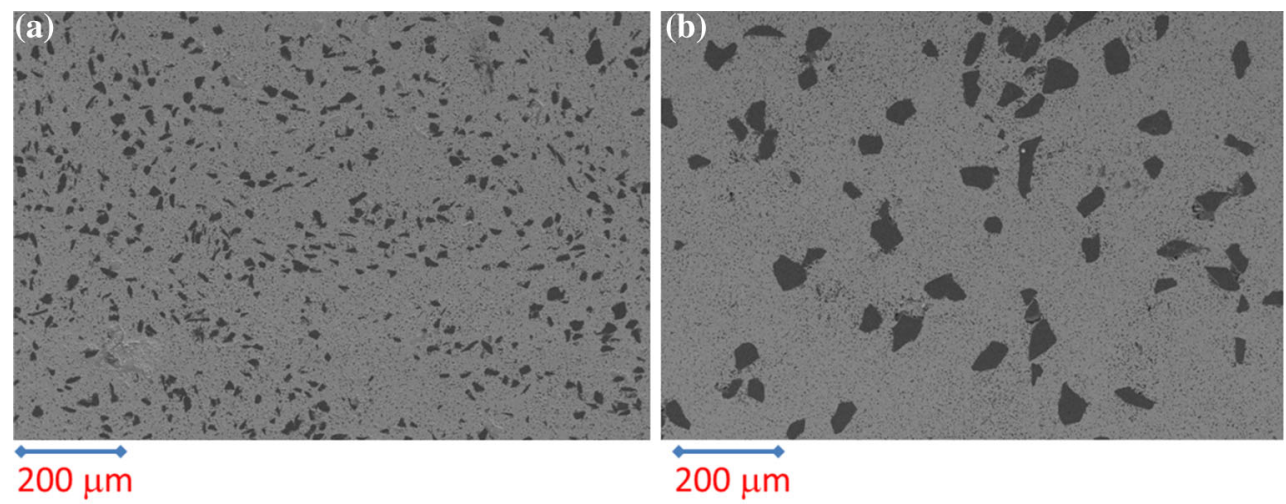

$200 \mu \mathrm{m}$
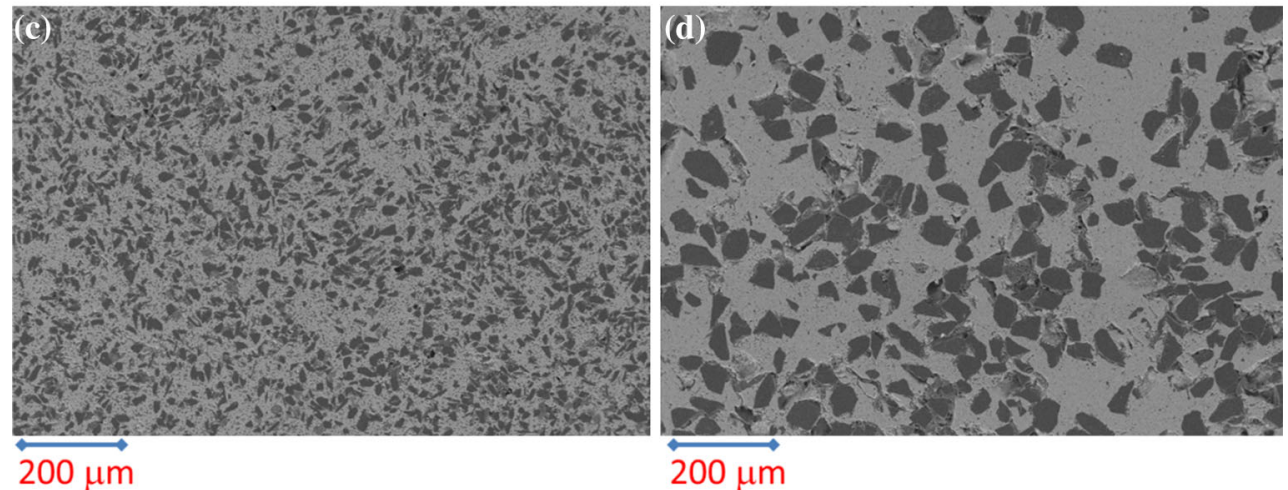

Fig. 2 BS SEM micrographs showing a $10 \mathrm{wt} \% 7-\mu \mathrm{m} \mathrm{B}{ }_{4} \mathrm{C}$, b $10 \mathrm{wt} \% 70-\mu \mathrm{m} \mathrm{B} \mathrm{B}_{4} \mathrm{C}$, c $30 \mathrm{wt} \% 7-\mu \mathrm{m} \mathrm{B}{ }_{4} \mathrm{C}$, d $30 \mathrm{wt} \% 70-\mu \mathrm{m} \mathrm{B}_{4} \mathrm{C}$ dispersed in SiC. $\mathrm{B}_{4} \mathrm{C}$ is the darker phase in each micrograph

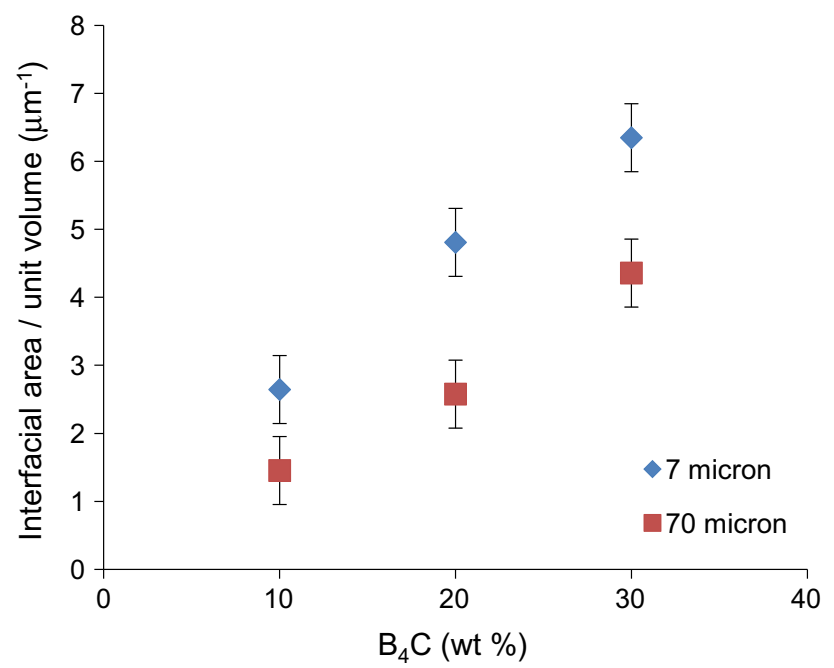

Fig. 3 Effect of wt $\% \mathrm{~B}_{4} \mathrm{C}$ content on interfacial area between the $\mathrm{SiC}$ and $\mathrm{B}_{4} \mathrm{C}$ for samples containing two different $\mathrm{B}_{4} \mathrm{C}$ sizes

\section{Densification}

The effect of $\mathrm{B}_{4} \mathrm{C}$ content on $\% \mathrm{TD}$ achieved in these composites after sintering for each $\mathrm{B}_{4} \mathrm{C}$ size used is shown in Fig. 4. Figure 5 shows the same data plotted as a function of the $\mathrm{SiC} / \mathrm{B}_{4} \mathrm{C}$ interfacial area for these materials.

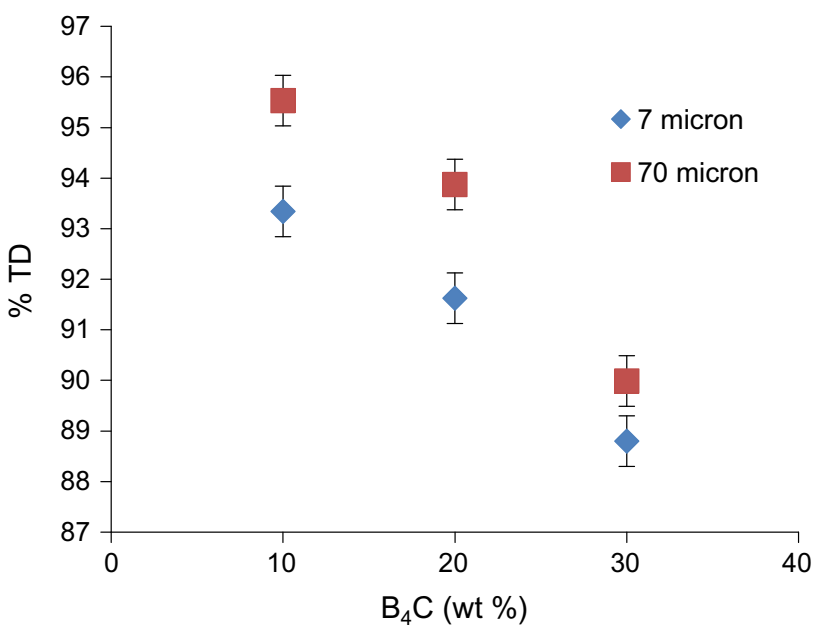

Fig. 4 Effect of $\mathrm{B}_{4} \mathrm{C}$ content on \% $\mathrm{TD}$ for samples containing two different $\mathrm{B}_{4} \mathrm{C}$ sizes

This can be used to understand the observed relationships between addition level, size and \%TD. In Fig. 5, the data are compared with the standard $\mathrm{SiC}$ material, which is assumed to have no interfacial area/unit volume. Though the fine $\mathrm{B}_{4} \mathrm{C}$ added as a sintering aid will generate some $\mathrm{SiC} / \mathrm{B}_{4} \mathrm{C}$ interfaces, the method employed to quantify the interfacial area for the coarse $\mathrm{B}_{4} \mathrm{C}$ will not have selected 


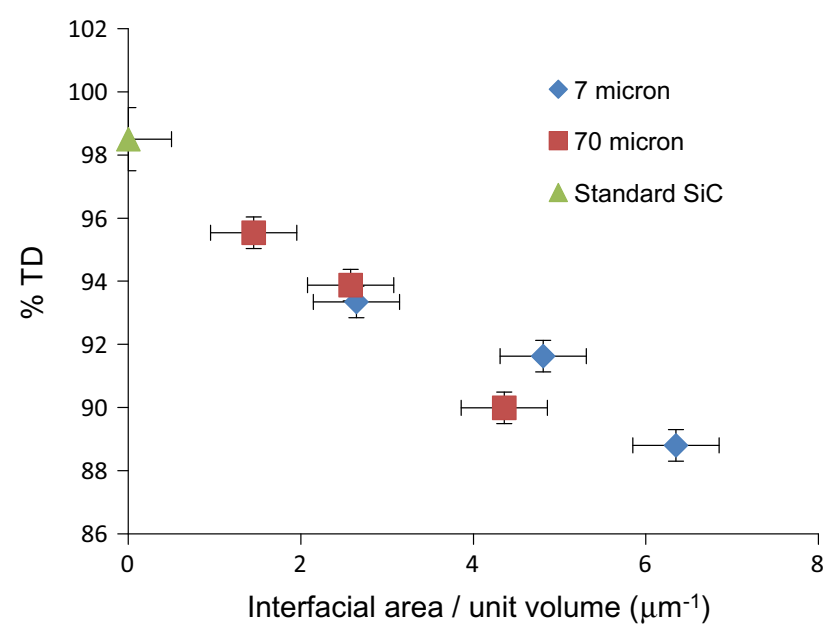

Fig. 5 Effect of $\mathrm{SiC} / \mathrm{B}_{4} \mathrm{C}$ interfacial area/unit volume on \%TD for samples containing two different $\mathrm{B}_{4} \mathrm{C}$ sizes, compared with a standard $\mathrm{SiC}$

the fine particles, due to the scale of the image used. Hence, in all materials measured, the fine $\mathrm{B}_{4} \mathrm{C}$ contributes effectively nothing to the interfacial area/unit volume.

Figure 4 shows that increasing the wt $\% \mathrm{~B}_{4} \mathrm{C}$ decreases the $\% \mathrm{TD}$ achieved. Although final \%TD is higher when using $70-\mu \mathrm{m}_{4} \mathrm{C}$, it might have been expected that the finer, 7- $\mu \mathrm{m}_{4} \mathrm{C}$ would have produced a higher degree of densification, as it had the greater curvature.

It is possible that the differing $\mathrm{O}$ content of the $\mathrm{B}_{4} \mathrm{C}$ powders is affecting densification behaviour; $\mathrm{O}$ contamination may affect the diffusivity at the surfaces and grain boundaries of the $\mathrm{SiC}$ particles during sintering. However, while the $7-\mu \mathrm{m} \mathrm{B}_{4} \mathrm{C}$ has approximately four times the $\mathrm{O}$ content of the $70-\mu \mathrm{m} \mathrm{B}_{4} \mathrm{C}$, the $\mathrm{SiC}$ has a far higher $\mathrm{O}$ content than either; $0.83 \mathrm{wt} \%$ compared with $0.16 \mathrm{wt} \%$ for the $7-\mu \mathrm{m} \mathrm{B}{ }_{4} \mathrm{C}$. As a result of this, the total $\mathrm{O}$ content from the powders results mostly from $\mathrm{SiC}$ and does not vary much between materials. It is likely this total $\mathrm{O}$ content will affect the densification behaviour, since the $\mathrm{B}_{4} \mathrm{C}$ is inert, with shrinkage occurring in the SiC. Finally, the fourfold increase in $\mathrm{O}$ content corresponds with a ten fold increase in specific surface area. Therefore, assuming that the $\mathrm{O}$ is found predominantly at the surface of the $\mathrm{B}_{4} \mathrm{C}$ particles, the thickness of the $\mathrm{O}$ coating does not increase with decreasing particle size. Hence, the presence and amount of $\mathrm{SiC} / \mathrm{B}_{4} \mathrm{C}$ interfaces themselves may be a more important factor than the $\mathrm{O}$ content of each $\mathrm{B}_{4} \mathrm{C}$ powder. This is supported by Fig. 5, which shows that the \%TD decreases as the $\mathrm{SiC} / \mathrm{B}_{4} \mathrm{C}$ interfacial area increases and this trend is constant across both $\mathrm{B}_{4} \mathrm{C}$ sizes and the reference material containing no coarse $\mathrm{B}_{4} \mathrm{C}$. Therefore, samples with 7- $\mu \mathrm{m} \mathrm{B}_{4} \mathrm{C}$ show lower \%TD than those with 70- $\mu \mathrm{m}$ $\mathrm{B}_{4} \mathrm{C}$ at equal wt $\%$ addition because finer $\mathrm{B}_{4} \mathrm{C}$ generates more interfacial area. This will reduce the number of $\mathrm{SiC} /$ $\mathrm{SiC}$ particle contacts in the material. As a result of this, less mass transport which contributes to densification occurs where $\mathrm{SiC} / \mathrm{B}_{4} \mathrm{C}$ interfaces exist. The driving force for densification is lowest when there is the greatest amount of $\mathrm{SiC} / \mathrm{B}_{4} \mathrm{C}$ interfacial area. Additionally, it seems likely that $\mathrm{SiC} / \mathrm{B}_{4} \mathrm{C}$ interfaces give a lower driving force for densification than $\mathrm{SiC} / \mathrm{SiC}$ interfaces. This may be because of the lattice mismatch between $\mathrm{SiC}$ and $\mathrm{B}_{4} \mathrm{C}$ raising the energy of these interfaces and also the low curvature of the $\mathrm{B}_{4} \mathrm{C}$ particles reducing the driving force for densification of these particles. It should also be noted that the material with $30 \mathrm{wt} \%$ 70- $\mu \mathrm{m} \quad \mathrm{B}_{4} \mathrm{C}$ shows somewhat lower \% TD than may be predicted from the trend observed in other materials. This may be because the numerous large $\mathrm{B}_{4} \mathrm{C}$ grains, which do not shrink during densification, exert a more significant pressure during sintering [28].

Given the observation that with a $d_{50}$ above $\sim 8 \mu \mathrm{m}$, $\mathrm{B}_{4} \mathrm{C}$ cannot self densify [5], in these materials any $\mathrm{B}_{4} \mathrm{C} /$ $\mathrm{B}_{4} \mathrm{C}$ contacts will tend to trap porosity. However, it may be speculated that with a finer $\mathrm{B}_{4} \mathrm{C}$, which can effectively selfdensify, additional driving force for densification would be created at any $\mathrm{B}_{4} \mathrm{C} / \mathrm{B}_{4} \mathrm{C}$ contacts. Further, the higher curvature of the particles may increase the driving force for densification at the $\mathrm{SiC} / \mathrm{B}_{4} \mathrm{C}$ interfaces. These materials would therefore occupy a different regime to those in the present study.

\section{Microstructure}

The $\mathrm{SiC} / \mathrm{B}_{4} \mathrm{C}$ interfacial area can also influence grain growth in the $\mathrm{SiC}$. Example $\mathrm{SiC}$ grain structures from different materials are shown in Fig. 6. The large pore-like features in Fig. 6 are of a similar size to the $\mathrm{B}_{4} \mathrm{C}$ features as shown in Fig. 2 and are therefore probably caused by the removal of $\mathrm{B}_{4} \mathrm{C}$. From comparison of micrographs before and after the etching process used, it appears that the etching tends to remove $\mathrm{B}_{4} \mathrm{C}$ features, possibly because the interfaces between the coarse $\mathrm{B}_{4} \mathrm{C}$ and the $\mathrm{SiC}$ matrix are weaker and so are more strongly affected by the etchant. The relationship between $\mathrm{SiC} / \mathrm{B}_{4} \mathrm{C}$ interfacial area and mean grain length for the materials produced for the present study is shown in Fig. 7.

Figure 7 shows that, across both $\mathrm{B}_{4} \mathrm{C}$ sizes, increasing the interfacial area between the phases seems to reduce $\mathrm{SiC}$ grain growth. With a greater $\mathrm{SiC} / \mathrm{B}_{4} \mathrm{C}$ interfacial area, there is a greater probability that a growing $\mathrm{SiC}$ grain will meet a $\mathrm{SiC} / \mathrm{B}_{4} \mathrm{C}$ interface and be physically stopped from growing. As with densification, the $\mathrm{O}$ content could also affect the grain growth by altering the relative rates of different mass transport mechanisms. However, as previously noted, the total $\mathrm{O}$ content is likely to be important and this is dominated by the $\mathrm{SiC}$, so it does not vary much. 

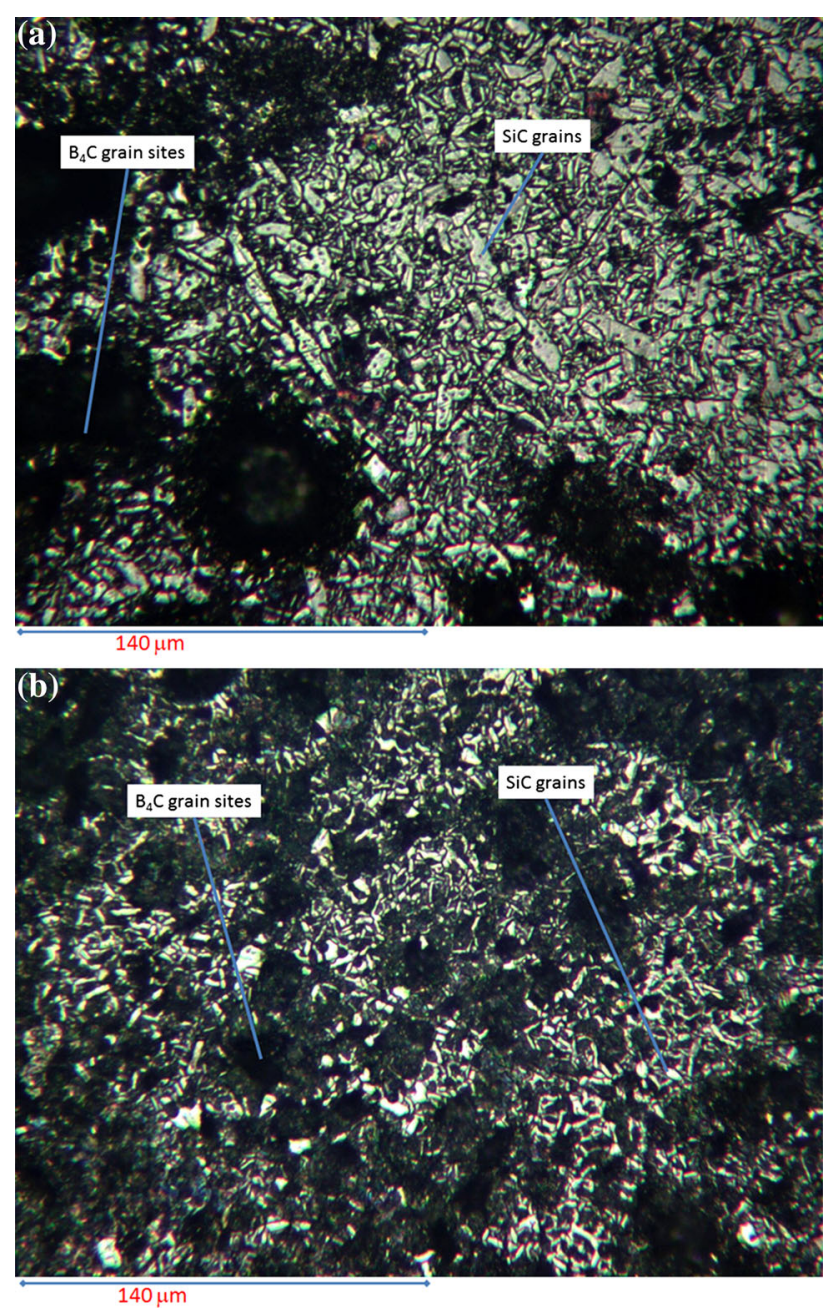

Fig. 6 Reflected light micrograph of polished and etched composites with $20 \mathrm{wt} \% \mathrm{~B}_{4} \mathrm{C}, \mathbf{a} 70-\mu \mathrm{m} \mathrm{B}{ }_{4} \mathrm{C}$, b $7-\mu \mathrm{m} \mathrm{B}_{4} \mathrm{C}$
Given that the addition of $\mathrm{B}_{4} \mathrm{C}$ typically reduced the observed grain growth, it was hypothesised that it may also affect the SiC polytype composition in the sintered body. Example XRD data used to analyse the polytype composition in these materials are shown in Fig. 8.

The effect of increasing interfacial area between the two phases on the vol\% $4 \mathrm{H}$ formed, as determined by XRD and Rietveld refinement, for materials sintered at $2125^{\circ} \mathrm{C}$, is shown in Fig. 9. This graph shows that less $4 \mathrm{H}$ is observed as the interfacial area between the phases increases, which is also when there is less grain growth. As with other properties, this trend also continues to the standard $\mathrm{SiC}$ with no coarse $\mathrm{B}_{4} \mathrm{C}$. The error in this measurement was determined from the estimated error produced in the model. The vol\% $\mathrm{B}_{4} \mathrm{C}$ in the material has also been calculated in the refinement for all materials tested and compared with the known value from the starting mass ratio of the powders. This indicates that there may be a systematic error present in the refinement data, since the vol\% $\mathrm{B}_{4} \mathrm{C}$ in the material estimated by the refinement model is consistently lower than the known true value. This may result from the disorder within the $\mathrm{B}_{4} \mathrm{C}$ structure causing uncertainty when fitting of the crystallographic data using existing structure models. Analysis of micrographs used to determine interfacial area in the sintered materials shows area $\% \mathrm{~B}_{4} \mathrm{C}$ consistent with the theoretical volume $\%$ that should be present based on the wt $\%$ added to the powder blend, assuming the materials are isotropic. Therefore, the refinement model is definitely inaccurate for the $\mathrm{B}_{4} \mathrm{C}$. However, the refinements of all six materials tested are self consistent, having been analysed using the same $\mathrm{B}_{4} \mathrm{C}$ structure file.
Fig. 7 Effect of interfacial area/unit volume on mean $\mathrm{SiC}$ grain length in sintered samples with two sizes of $\mathrm{B}_{4} \mathrm{C}$, compared with standard $\mathrm{SiC}$

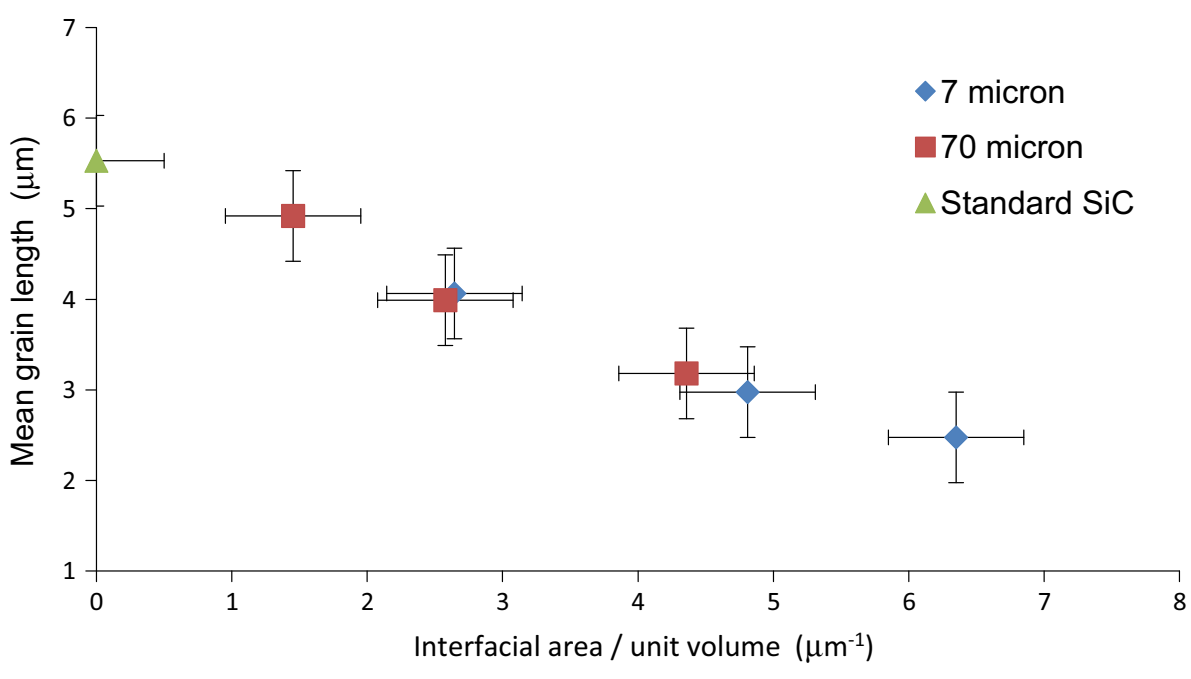


Fig. 8 XRD data used in Rietveld refinement of sample materials analysed, a $10 \mathrm{wt} \%$ $70-\mu \mathrm{m} \mathrm{B}_{4} \mathrm{C}$ and $\mathbf{b} 30 \mathrm{wt} \% 7-\mu \mathrm{m}$ $\mathrm{B}_{4} \mathrm{C}$, with key peaks generated from the structure files of the two major $\mathrm{SiC}$ polytypes and $\mathrm{B}_{4} \mathrm{C}$ phase used
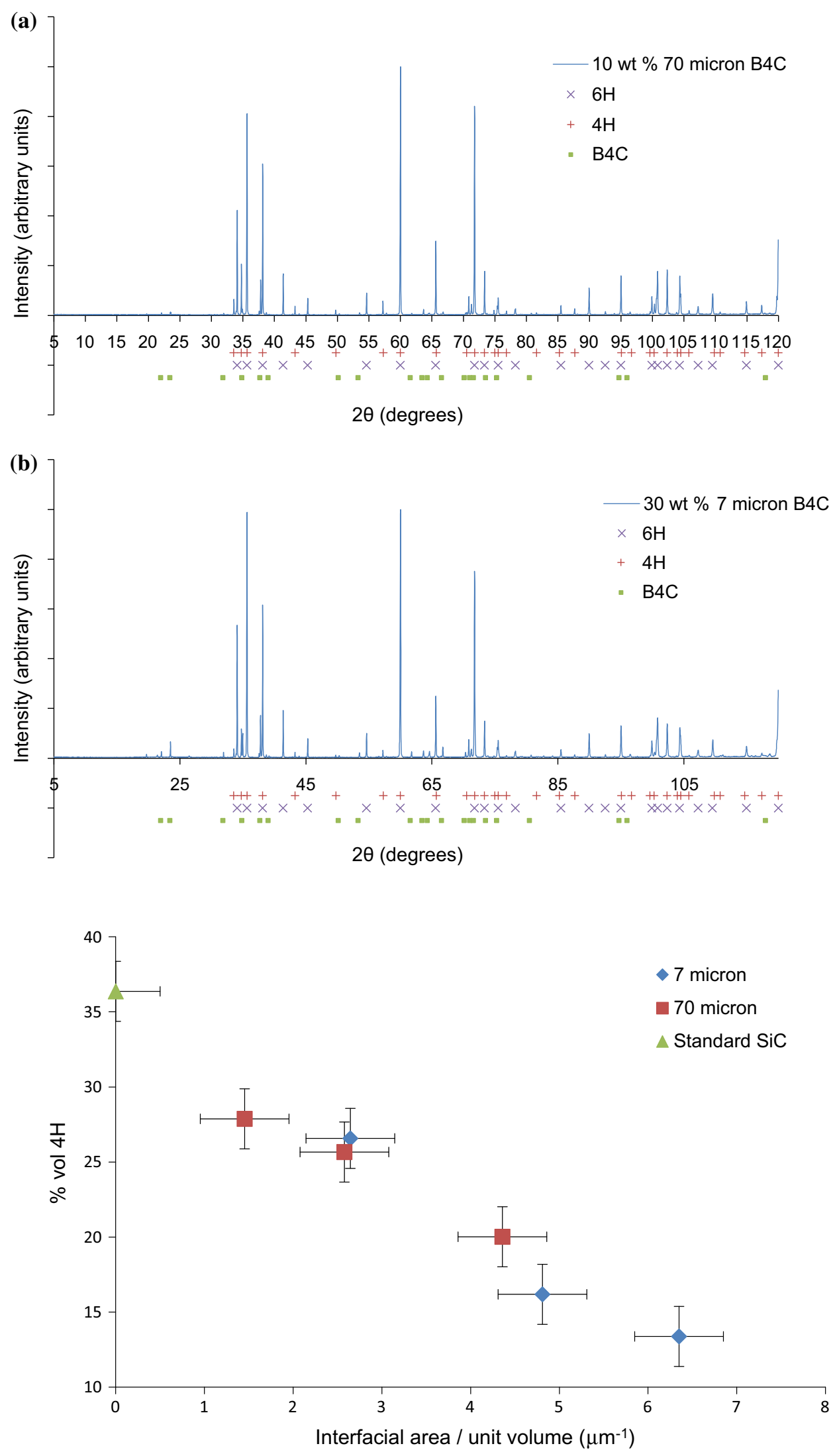

Fig. 9 Effect of interfacial area as determined by the 'edge area' method on vol\% $4 \mathrm{H}$ in sintered samples 
An increase in transformation to $4 \mathrm{H}$ with increased grain growth has been previously observed for LPS $\alpha$-SiC [19]. From comparison with Fig. 7 , increase in vol $\% 4 \mathrm{H}$ corresponds to increasing grain length. This may be because the growth mechanism producing the larger $\mathrm{SiC}$ grains involves a transformation from $6 \mathrm{H}$ to $4 \mathrm{H}$. However, the present system would normally be expected to give solid state sintering with no liquid phase present. It is possible that small volumes of a liquid phase may have formed, possibly a $\mathrm{Si}-\mathrm{B}-\mathrm{C}$ eutectic, which is believed to cause abnormal grain growth [13], or alternatively that the solid state grain growth mechanism also involves a polytype transformation. While further work would be needed to determine whether this is the operative mechanism in the present study, there does seem to be a correlation between grain growth, amount of $4 \mathrm{H}$ formed and the interfacial area in the material.

\section{Concluding remarks}

This study has examined the effect of interfacial area/unit volume, a quantified microstructural parameter, on the sintering behaviour of $\mathrm{SiC} / \mathrm{B}_{4} \mathrm{C}$ particulate composites. The following conclusions can be reached:

- The amount of $\mathrm{SiC} / \mathrm{B}_{4} \mathrm{C}$ interfacial area in a composite has a controlling effect on the microstructure evolution of these materials.

- Densification is inhibited by $\mathrm{SiC} / \mathrm{B}_{4} \mathrm{C}$ interfaces at the sintering temperature tested.

- Increased $\mathrm{SiC} / \mathrm{B}_{4} \mathrm{C}$ interfacial area reduces the grain growth observed in the $\mathrm{SiC}$ matrix, possibly by physically impeding the growing $\mathrm{SiC}$ grains.

- Increased interfacial area correlates with decreased transformation of $\mathrm{SiC}$ from $6 \mathrm{H}$ to $4 \mathrm{H}$ during sintering, in parallel with reduced grain growth.

Acknowledgements The Authors would like to acknowledge EPSRC and Dstl for funding this work, Morgan Advanced Materials for provision of equipment and expertise and Dr. Julia Percival for assistance with the GSAS software. This work was carried out as part of an Engineering Doctorate Programme in Micro- and NanoMaterials and Technologies at the University of Surrey, grant number EP/G037388/1.

\section{Compliance with ethical standards}

Conflict of interest The authors declare that they have no conflict of interest.

Open Access This article is distributed under the terms of the Creative Commons Attribution 4.0 International License (http://crea tivecommons.org/licenses/by/4.0/), which permits unrestricted use, distribution, and reproduction in any medium, provided you give appropriate credit to the original author(s) and the source, provide a link to the Creative Commons license, and indicate if changes were made.

\section{References}

1. Kuzenkova MA, Kislyi PS, Grabchuk BL et al (1979) The structure and properties of sintered boron carbide. J Less Common Met 67:217-223

2. Karandikar PG, Wong S, Evans G et al (2010) Microstructural development and phase changes in reaction bonded boron carbide. Ceram Eng Sci Proc 31:251-259

3. Pittari J III, Subhash G, Trachet A et al (2015) The rate-dependent response of pressureless-sintered and reaction-bonded silicon carbide-based ceramics. Int J Appl Ceram Technol 12:207-216

4. Vandeperre LJ, Teo JH (2014) Pressureless sintering of SiC-B ${ }_{4} \mathrm{C}$ composites. Ceram Eng Sci Proc 34:101

5. Schwetz KA, Grellner W (1981) The influence of carbon on the microstructure and mechanical properties of sintered boron carbide. J Less Common Met 82:37-47

6. Padture NP (1994) In situ-toughened silicon carbide. J Am Ceram Soc 77:519-523

7. Stobierski L, Gubernat A (2003) Sintering of silicon carbide I. Effect of carbon. Ceram Int 29:287-292

8. Wereszczak AA, Lin H-, Gilde GA (2006) The effect of grain growth on hardness in hot-pressed silicon carbides. J Mater Sci 41:4996-5000. doi:10.1007/s10853-006-0110-z

9. Hamminger R (1989) Carbon inclusions in sintered silicon carbide. J Am Ceram Soc 72:1741-1744

10. Jung $\mathrm{CH}$, Kim $\mathrm{CH}$ (1991) Sintering and characterization of $\mathrm{Al}_{2} \mathrm{O}_{3}-\mathrm{B}_{4} \mathrm{C}$ composites. J Mater Sci 26:5037-5040. doi:10.1007/ BF00549888

11. Lin X, Ownby PD (2000) Pressureless sintering of $B_{4} C$ whisker reinforced $\mathrm{Al}_{2} \mathrm{O}_{3}$ matrix composites. J Mater Sci 35:411-418. doi:10.1023/A:1004715300441

12. Górny G, Rączka M, Stobierski L et al (1997) Microstructureproperty relationship in $\mathrm{B}_{4} \mathrm{C}-\beta \mathrm{SiC}$ materials. Solid State Ion 101-103:953-958

13. Stobierski L, Gubernat A (2003) Sintering of silicon carbide II. Effect of boron. Ceram Int 29:355-361

14. Shaffer PTB (1970) Solubility of boron in alpha silicon carbide. Mater Res Bull 5:519-521

15. Magnani G, Beltrami G, Minoccari GL et al (2001) Pressureless sintering and properties of alphaSiC- $\mathrm{B}_{4} \mathrm{C}$ composite. J Eur Ceram Soc 21:633-638

16. Shih CJ, Meyers MA, Nesterenko VF et al (2000) Damage evolution in dynamic deformation of silicon carbide. Acta Mater 48:2399-2420

17. Groth B, Haber R, Mann A (2014) Raman micro-spectroscopy of polytype and structural changes in $6 \mathrm{H}$-silicon carbide due to machining. Int J Appl Ceram Technol 12:795-804

18. Sigl LS, Kleebe HJ (1993) Core/rim structure of liquid-phasesintered silicon carbide. J Am Ceram Soc 76:773-776

19. Zhou Y, Tanaka H, Otani S et al (1999) Low-temperature pressureless sintering of alpha-SiC with $\mathrm{Al}_{4} \mathrm{C}_{3}-\mathrm{B}_{4} \mathrm{C}-\mathrm{C}$ additions. J Am Ceram Soc 82:1959-1964

20. Tanaka H, Zhou Y (1999) Low temperature sintering and elongated grain growth of $6 \mathrm{H}-\mathrm{SiC}$ powder with $\mathrm{AlB}_{2}$ and $\mathrm{C}$ additives. J Mater Res 14:518-522

21. Tanaka H, Yoshimura HN, Otani S et al (2000) Influence of silica and aluminum contents on sintering of and grain growth in $6 \mathrm{H}-$ SiC powders. J Am Ceram Soc 83:226-228

22. Tanaka H, Hirosaki N, Nishimura T et al (2003) Nonequiaxial grain growth and polytype transformation of sintered $\alpha$-silicon carbide and $\beta$-silicon carbide. J Am Ceram Soc 86:2222-2224 
23. Lee SK, Kim CH (1994) Effects of $\alpha$-SiC versus $\beta$-SiC starting powders on microstructure and fracture toughness of $\mathrm{SiC}$ sintered with $\mathrm{Al}_{2} \mathrm{O}_{3}-\mathrm{Y}_{2} \mathrm{O}_{3}$ additives. J Am Ceram Soc 77:1655-1658

24. Gurland J (1967) A study of contact and contiguity of dispersions in opaque samples. In: Elias H (ed) Stereology. Springer, Berlin, pp 250-251

25. Morosin B, Mullendore AW, Emin D et al (1986) Rhombohedral crystal structure of compounds containing boron-rich icosahedra. AIP Conf Proc 86:70-86
26. Bind JM (1978) Phase transformation during hot-pressing of cubic SiC. Mater Res Bull 13:91-96

27. Capitani GC, Di Pierro S, Tempesta G (2007) The 6H-(SiC) structure model: further refinement from SCXRD data from a terrestrial moissanite. Am Miner 92:403-407

28. Bordia RK, Scherer GW (1988) On constrained sintering-III. Rigid inclusions. Acta Metall 36:2411-2416 